\title{
The limits of guanxi capitalism: transnational collaboration between Taiwan and the USA
}

\author{
Jinn-Yuh Hsu \\ Department of Geography, National Taiwan Normal University, Taipei, Taiwan, Republic of \\ China; e-mail: jinnyuh@cc.ntnu.edu.tw
}

\section{AnnaLee Saxenian}

Department of City and Regional Planning, University of California at Berkeley, CA 94720, USA; e-mail: anno@socrates.berkeley.edu

Received 5 May 2000; in revised form 4 August 2000

\begin{abstract}
In this research we explore the relationship between high-technology regional development and ethnic networks in the connection between Silicon Valley, California and Hsinchu, Taiwan. We elaborate the argument that regional industrial structure and embedded social networks, rather than the multinational firm, should be the focus in the study of transnational business. The complementary regional industrial structures allow economic and technological collaboration between these two regions while the social networks help coordinate these transnational (cross-regional) collaborations. However, we seek to distinguish this account from the dominant perceptions of the role of guanxi (interpersonal relationships) in overseas Chinese business networks (OCBN). In contrast with the arguments for OCBN, that guanxi provides resources for Chinese firms to coordinate and control transnational business, we argue that the skill and competence required for technological upgrading are not necessarily guaranteed within the ethnic network. Although ethnic networks facilitate transnational business and technology cross-fertilization, it seems go too far to argue the Silicon Valley-Hsinchu connection is another version of Chinese guanxi capitalism.
\end{abstract}

"For many generations, emigrant Chinese entrepreneurs have been operating comfortably in a network of family and clan, laying the foundations for stronger links among businesses across national borders. And Chinese-owned businesses in East Asia, the United States, Canada, and even farther afield are increasingly becoming part of what I call the Chinese commonwealth".

Kao (1993, page 24)

"In Chinese society, system trust is based on normative, intersubjective rules that link people who are classified according to relational categories into networks and that specify their modes of interaction in Chinese society, system trust is highly personalized ...."

Hamilton (1996, page 1004)

"Kenny Liu, Jerry Chang, and David Lin all worked together at Silicon Valley-based Chips \& Technologies before founding Opti in 1989. After being rebuffed by mainstream venture capitalists, they raised $\$ 1$ million in seed capital from a mutual friend in Taiwan. When the company went public in 1993 it had over 200 employees in Silicon Valley (70\% of whom were Chinese) and over $\$ 100$ million in sales. The early customers for their chipsets were all in Asia, largely Taiwanese personal computer companies; and their vendors were the leading Taiwanese semiconductor foundries, TSMC and UMC."

(author's interview)

In this paper we critically evaluate arguments about the importance of Chinese business networks and guanxi (or interpersonal relationship) to the process of globalization, and we use the case of the economic connections between Silicon Valley and Taiwan's Hsinchu region to reveal the limits of such concepts. One of the most promising 
contributions to recent debates about globalization is the literature that analyzes the interplay between the various scales of economic activity, from the local to the global (Cox, 1997). These theorists recognize that the process of globalization is constituted by the complex relationships between multiple different local systems - that we are in an era of glocalization, rather than globalization.

The key challenge for this perspective is to understand how producers cope with the interface between the local and the global, or the governance mechanism in the glocalization process. Some writers take the multinational corporation as the core economic actor in a global hierarchical fiat system (Dicken, 1998). Others conceive of the global system as a network of regional worlds (Scott, 1998). Within this networkgoverned economy, social ties between communities in the interacting regions are a central concern. Rather than taking the large corporation as the major actor, the network approach focuses on the social embeddedness of the ostensibly profit-oriented business world. The latter approach leads students of economic systems to bring the social back in, even at the global level (Castells, 1996; Saxenian and Hsu, 1999). Scholars adopting this network approach to globalization have focused on the role of ethnic ties, in particular, to explain the accelerated growth of cross-border economic transactions (Dicken and Yeung, 1999; Kao, 1993). They see social networks, not asocial economic rationality, as the basis for the emergence of economic transnationalism. In contrast to theories of the product life cycle or new international division of labor, which focus on the multinational corporation, this view sees the members of the ethnic diaspora constructing the technological and financial bridges between distant regional economies.

The dominant example of this approach is the analysis of overseas Chinese business networks (OCBN). Students of what Kao refers to as the "global web" of Chinese business see the close ties between overseas Chinese and local Chinese communities as a central mechanism for economic cross-fertilization in the Pacific Rim. In this view, global economic transactions are enhanced by the advantage of blood bonds. Ethnic ties render the utilization and coordination of resources among firms of the crossborder regions flexible and economical, and hence reinforce their competitiveness (Borrus, 1997; Kao, 1993; Kotkin, 1992).

Other students of Chinese capitalism stress the mediating role of guanxi in economic transactions among ethnic Chinese businesses, both local and cross-border (Hamilton, 1996; Hsing, 1998; Yeung, 1998). They claim that the Chinese cultivation of personal relationships, or guanxi, institutionalizes the trust, loyalty, reciprocity, and reputation that facilitate efficient business operations. As Hsing (1997, page 144) argued, "Most writers agree that the foundation of the Chinese Style of business organization is familism (which usually includes nepotism, paternalism, and family ownership in firm organization) and interpersonal relationships-guanxi, on which a trusting and reciprocal obligatory relationship is built between business partners." In other words, cooperation, or cooperative competition, is the norm in the guanxibased Chinese business world. Such a system is seen as particularly advantageous in the current economic environment as it allows the members of the network quickly to identify complementary assets and build close partnerships at a global scale. Wong and Salaff (1998) argue, for example, that such "network capital"(1) can create relationships with low redundancy and allows producers to recruit efficiently and focus resources on economic competition.

(1) Wong and Salaff (1998, page 359) define "network capital" as a type of capitals (along with social and economic capitals), which is cultivated by guanxi building, and is an asset capable of conferring strength, power, and consequently profit on their holder. 
Such arguments reveal important truths about cross-border business networks. No doubt ethnic ties and interpersonal relationships can facilitate collaboration and reduce the uncertainty of economic deals. Shared language and culture can also help producers, even those located at great distances, gather information about people, capital, and other resources within the community. In other words, such social ties fulfill the need for 'know-who' in the learning economy in which the social dimension is the key and often ignored issue in the constitution of competitiveness (Lundvall, 1996).

However, this is not the end. Students of OCBN claim that Chinese businesses can exploit their privileged ability to recognize worldwide market differences, or what Kao (1993) refers to as "knowledge arbitrage". From this perspective, market differences can be translated into geographical market differences, and then into regional comparative advantage, as Borrus (1997) argues for Asian production networks.

Such arguments conflate access to market information and firm capabilities. Market information - information about product supply and demand-is one thing. A firm's competencies, including knowledge about product innovations, specification definition, and process improvement, is another. Privileged access to information does not equate to construction of corporate capabilities. Although the goodwill cultivated from the ethnic web can undoubtedly accelerate the flow of information it cannot substitute for the longer term creation of a firm's competitive capabilities.

Moreover, while the OCBN arguments implicitly presume a unified, even monolithic, Chinese business community, an emerging literature on the Chinese diaspora recognizes multiple ethnic subgroups. One such distinction, between affluent Chinese managers and professionals and their less educated counterparts (Lin, 1998), is often reflected in residential patterns. Wealthy Chinese tend to live in suburban areas, while lower income Chinese are heavily concentrated in inner-city Chinatowns. Although these subgroups are of the same ethnicity, they typically possess different language skills, property assets, technical training, business worlds, and even subcultures. Take, for example, the Chinese diaspora in the San Francisco Bay Area. Whereas residents of the Oakland and San Francisco Chinatowns live on the grocery trade and garment industry, the South Bay suburban Chinese contribute to the glamour of Silicon Valley. Whereas residents of Chinatown confine themselves to the ethnic enclave, the Silicon Valley Chinese work hard to merge with the dominant American society (Saxenian, 1999). It is hard to imagine that these two subgroups of overseas Chinese will constitute a unified identity let alone engage for mutual benefit in economic transactions.

The OCBN argument also overlooks the danger of lock-in in the ethnic business circle. Although the ethnic enclave is a good strategy for survival, it is a bad arrangement for global competition. Zhou (1992) demonstrates that the abundance of cheap ethnic labor in New York's Chinatown removes a stimulus for innovation among local producers. The ethnic buffer developed to protect against outsiders can too easily become insulation from new ideas. Dense ties grow too dense to be broken to form new ties, undermining the ability to balance the coupling and decoupling needed for economic success within ethnic networks (Granovetter, 1995).

The discourse of guanxi capitalism, by contrast, widens the scope of business networks to include nonblood bonds. Because guanxi is constructed rather than embedded, such arguments avoid the pitfalls of lock-in by allowing for the creation of divergent social networks within the Chinese community.

However, such a constructivist interpretation of guanxi loses its rigor as a social category. Rather it becomes a chaotic concept that refers to different, even contradictory, meanings. Yeung (1998), for example, describes guanxi as a sort of 'atmosphere' to engender the growth or solidarity of ongoing relationships within personal and business networks. He divides it into seven key components: trust, loyalty, obligation, reputation, 
reliability, respect, and sentiment. It is true that these elements can lubricate the process of economic transactions. However, it is essential to distinguish, for example, different modes of trust building: whereas 'blind' trust can be created on the base of obligation, loyalty, and sentiment, the 'studied' trust that insures mutually beneficial business collaborations can only be learned by monitoring (Sabel, 1994). A concept with so many connotations ultimately lacks explanatory power. Since it seems explain everything, in reality it explains nothing.

The guanxi argument, although more sophisticated than that of OCBN, still risks oversocializing economic behavior that is rooted in business and technological considerations. This is the blind spot in the discourse on social constitution, which assumes that social relationships determine economic transactions and outcomes.

The economy is not reducible to interpersonal relationships, but composed of multiple production worlds that are defined by product configuration, market principles, and technology and production process (Storper and Salais, 1997). In other words, dense social ties cannot substitute for the sophisticated managerial and technological learning that is required to compete in a particular sector, in spite of the fact that the social dimension of learning is critical. Guanxi arguments overlook these complex differences. So the guanxi principle has been used to explain the organization both of Taiwan's traditional small and medium-sized enterprises (in sectors such as textiles and footwear) and of its newer technology producers (in sectors such as semiconductors and personal computers, PCs). As a result, the strength of affective relationships (or the sense of community) replaces the strength of managerial and technological expertise as the source of competitive advantage.

This takes the argument too far. First, it is hard to imagine that the labor market and labor training (or labor conventions) of intellectual workers in sectors such as semiconductors and computer software will follow the same trajectory defined by craft workers in traditional sectors such as garments and shoes. We should in theory be able to specify the difference between social relations and economic networks, while agreeing that they are interrelated in practice.

Second, more and more research findings disclose that guanxi arguments just dress up bureaucratic rent-seeking behaviors in an institutionally deficient environment such as the new open-door China (Guthrie, 1998; Wu J-M, 1997). Whereas Hsing (1997) takes the bribery behavior between Taiwanese business people and China's local bureaucrats to be an example of the advantage of cultural affinity, Cheng (1999) refutes it by demonstrating that fake joint ventures between Taiwan's small capitalists and China's local government are a buffer against disturbance by the bureaucrats. As the institutions become unambiguous, guanxi's role in business transactions will decline (Guthrie, 1998). In a word, guanxi arguments should be evaluated in a process of dynamic institutionalism, rather than a definite form of Chinese capitalism.

In the remainder of this paper we apply this conceptual approach to the evolution of the connection between Silicon Valley and Taiwan's Hsinchu region-a connection that, at first glance, appears an ideal typical case of the advantages provided by OCBN and of guanxi. Separating the social and economic (as well as the technological) aspects of this connection demonstrates the limits of such oversocialized explanations in explaining the cross-fertilization between the established technological hub, Silicon Valley, and the emerging learning region, Hsinchu.

We suggest that the growth of social and economic ties between individuals and firms in the two regions enhances the performance of both Silicon Valley and Hsinchu. The key actors in this story are a transnational community of US-educated Taiwanese engineers who have the language skills and experience to operate fluently in both regions. Their dense social and professional networks foster two-way flows 
of technology, capital, know-how, and information between the USA and Taiwan, supporting entrepreneurship in both regions while also providing the foundation for formal interregional business relations such as consortia, joint ventures, and partnerships.

This case suggests that collaboration between producers located in differently specialized but similarly organized regional economies can foster a positive-sum dynamic of reciprocal industrial advance. These interregional relationships support entrepreneurial success in both regions by supporting joint problem-solving and complementary innovation (Sabel, 1989). And like the relationships between specialist firms and their suppliers inside industrial districts, these interregional networks cannot be understood purely as market transactions or 'commodity chains' linking independent firms in different locations (Gereffi and Korzeniewicz, 1994). Rather, the economic ties are dependent upon a social structure and culture that foster openness and cooperation between producers in geographically distant regions. Close trustbased relationships among the transnational community of Taiwanese engineers are thus an essential precondition for the flexible collaboration needed to adapt and survive in today's fast-paced competitive environment.

However, this does not mean that the Silicon Valley-Hsinchu connection is just another case of OCBN or guanxi capitalism. Whereas students of Chinese capitalism emphasize the particularity of guanxi as the dominant organizational principle, we have already suggested that guanxi-embedded trust does not necessarily enhance firm and regional competencies. Although guanxi-incubated goodwill can render the coordination and allocation of resources between transacting firms easy and economical the capability needed for industrial upgrading is not guaranteed within the network. Even worse, the strong ties of guanxi can sometimes lead to the lock-in of obsolete technology.

In the case of Silicon Valley and Taiwan, the relationships that facilitate coordination and rapid adaptation in a fast-paced competitive environment are based on professional networks that are both constructed and continually monitored-not on inherited, cultural, or deep-rooted affective ties. There is no question that shared language, culture, and history facilitate the construction of shared identities among overseas Taiwanese. But in this case, social solidarity derives as much from common educational and professional experiences among engineers and scientists who have studied and worked together. These professional networks can facilitate economic transactions and managerial and technological learning. However, they do not insure the competitive capabilities of firms and regions.

\section{Methodology}

This paper is based on the findings of two research projects, which lasted for three years, from 1997 to 2000. The first project examined the social and professional networks of highly skilled Chinese and Indian immigrants in Silicon Valley, and the second one tracked the connections these immigrants were building back to their home countries. In the research process we conducted more than 100 interviews with entrepreneurs, senior engineers, chief executive officers, and venture capitalists, as well as representatives of key government agencies, business organizations, and other social groups in both Taiwan and Silicon Valley. At the beginning of the research, we proposed a temporary hypothesis about the interregional connections between Silicon Valley and Hsinchu based on our previous research (Hsu, 1997; Saxenian, 1994). Under the framework we developed a semistructured set of questions for our interviews. The interim framework allowed us to focus on the research topic and, at the same time, exposed us to feedback on our original hypotheses from the empirical world. As we gathered more information, we sharpened our points and raised more critical issues in the interviews. As a result, some informants (such as $\mathrm{Mr}$ Miin Wu who is a role model 
for Silicon Valley returnees in Hsinchu) were visited as many as three times to make the points clearer. In the corporate interviews, in particular, we were cautious to doublecheck the results of each interview with cross-references. These interviews typically lasted at least an hour and were conducted with native-language-speaking researchers who knew the social context well enough not to engender misunderstandings. After each interview, the researchers discussed the findings, encoded the information, and worked to challenge each other's viewpoints.

In addition, in-depth interviews, government publications, business surveys, and journal reports provided valuable materials for this research. However, in order to avoid turning the research into a collection of business anecdotes, we have been particularly careful in drawing conclusions from these reports. We double-checked with the relevant people or agencies before we made final judgments.

\section{The formation of the transnational technical community}

Silicon Valley's workforce has become increasingly international in the past several decades. US immigration reforms of the mid-1960s were designed to attract highly skilled immigrants and facilitated a classic brain drain. The 'best and the brightest' students from poor countries such as India, Taiwan, and China came to the USA for graduate studies and then stayed on to work in the fast-growing new technology companies in California and elsewhere. Today, foreign-born engineers account for close to one third of Silicon Valley's technical workforce-including more than 12000 from Taiwan (Saxenian, 1999).

Silicon Valley's Taiwanese engineers constructed close trust-based relationships that built on their shared educational and professional experiences. These engineers typically report that there are some thirty or forty members of each graduating class during the 1970s and 1980s from the leading Taiwanese universities working in Silicon Valley. These classmates stay in close touch with one another both informally and through the frequent activities of their alumni associations. In addition, a Joint Alumni Association, which unites thirty-one Taiwanese campuses, holds regular meetings. Some of these engineers even report staying in close touch with classmates from high school.

This makes the Taiwanese community in Silicon Valley a very small community. Just as there are close social ties among the American engineers in Silicon Valley (Saxenian, 1994), virtually all of the region's Taiwanese engineers report that their community is so tight that "everyone knows everyone else and how their businesses are doing" (interview). This can be a double-edged sword: on the one hand, it means that there is a tremendous amount of informal information exchange and support. Many of these engineers report that they can call on one another at any time and they are always willing to help one another out. On the other hand, the fact that word spreads quickly means that reputations can be made or broken very fast. This constant monitoring means that individuals - even of the same ethnicity - who fail to follow through on their commitments are often isolated.

This social solidarity is strengthened significantly by their status as immigrants sharing a common language and culture in a foreign country. However, the trust is not based simply on the cultural or familial ties of an overseas Chinese community (Kotkin, 1992; Seagrave, 1995). These social networks are rarely based, for example, on the traditional Chinese family, village, or surname associations. In fact, most of these engineers work alongside other Chinese immigrants, yet they report much closer ties with other Taiwanese than with Chinese from Hong Kong, the Mainland, or other parts of Asia. Rather they are rooted in shared professional identities and technological interests. 
A variety of organizations were formed in Silicon Valley during the 1970s and 1980s that helped construct shared identities among the region's Taiwanese community. The Chinese Institute of Engineers (CIE), a broad-based national technical and professional association, has a very active branch in Silicon Valley that meets regularly for seminars, dinners, and conferences. The CIE is active in promoting ties with engineers in Taiwan and China as well, and it is a bilingual association, sponsoring activities in both Mandarin Chinese and English. There are also many specialist associations that Taiwanese engineers are active in, including the Chinese Software Professional Association, the Chinese American Semiconductor Production Association, the Association of Taiwanese Engineers of North America, the Chinese-American Computer Association, and specialist associations of Chinese engineers in various fields, from aeronautics to electronic optics to civil and chemical engineering. These Taiwanese organizations are unusually vibrant even for a region that is known for active associational life. All sponsor seminars, monthly dinner meetings, annual conferences, and other social events (Saxenian and Hsu, 1999).

Although CIE was the first organization of Chinese engineers in the Bay Area, it had little contact with the extensive infrastructure of traditional ethnic associations in San Francisco's Chinatown, historically the center of Chinese immigration to the area. Most CIE members are highly educated professionals from Taiwan who live and work in the South Bay. They have little in common with the older generations of less skilled workers from Hong Kong and southern China, who lived and worked in San Francisco. Even today, these two communities of Chinese immigrants coexist with limited social or professional interaction.

This divide underscores the dangers of overstating the power of race in creating cohesive ethnic identities, which is often done in discussions of the business networks of overseas Chinese. Collective identities are constructed over time, often through the kinds of face-to-face social interactions that are facilitated by geographic, occupational, or industrial concentration. The initial social connections often have a basis in shared educational experiences, technical backgrounds, language, culture, and history. Once established, these concentrations promote the frequent and intensive interactions that breed a sense of commonality and identification with members of the same group - and at the same time, exclude others, even of similar racial characteristics.

This is not to suggest that these associations create entirely self-contained ethnic businesses or communities. Many Chinese immigrants socialize primarily within the ethnic networks, but routinely work with native-born engineers and native-run businesses. In fact, there is growing recognition within these communities that, although a start-up might be spawned with the support of the ethnic networks, it needs to become part of the mainstream in order to grow. It appears that the most successful immigrant entrepreneurs in Silicon Valley today are those who have drawn on ethnic resources while simultaneously integrating into mainstream technology and business networks. ${ }^{(2)}$

Silicon Valley provided an important entrepreneurial training ground for Chinese engineers as well as a supportive environment for the creation of a closely knit technical community. By 1999, Chinese were running 2001 Silicon Valley-based technology companies, or $17 \%$ of the companies started in the region since 1980 (Saxenian, 1999). Many immigrants eventually returned to Taiwan, to start companies there, while simultaneously maintaining close ties with former collegues and classmates in Silicon Valley. Not surprisingly, a majority of the Chinese companies in Silicon Valley are concentrated in computer and electronics hardware sectors, creating opportunities for

(2) This parallels Granovetter's (1995) notion of balancing coupling and decoupling in the case of overseas Chinese entrepreneurs. 
collaboration with their counterparts in Taiwan. This also creates the possibilities of cross-border collaboration between Silicon Valley and Hsinchu.

From the mid-1970s on, Taiwanese government officials recognized the potential assets of the Silicon-Valley-based Taiwanese technical community. They invited overseas Taiwanese entrepreneurs to invest back home, and organized some technical meetings to obtain advice from these high-technology people (Hsu, 1999). Initially the interaction between the overseas community and the home country were informal, such as sourcing capital from friends and relatives, providing consultancy for Taiwanese government, participating in individual investments and subcontracting manufacturing to Taiwanese firms. To welcome the return of overseas talents, the Taiwanese government set up the Hsinchu Science-based Industrial Park (HSIP) to provide a huge acreage of land, tax incentives, and public infrastructure to persuade the returnees to invest (Hsu, 1997). ${ }^{(3)}$

The connection became formalized as new bridging associations, such as the Monte Jade Science and Technology Association, were established in the late 1980s. Monte Jade was organized in 1989 by a group of senior Taiwanese engineers with the explicit intention of bringing together Chinese technologists in the Bay Area and Taiwan to promote business cooperation, investment, and technology transfer between executives and companies in Taiwan and the USA. Today the organization has 150 corporate members in the Silicon Valley branch, including the leading Taiwanese technology companies, and 300 individual members. One of Monte Jade's primary objectives, as stated in its statute, is to "open up opportunities for professionals and corporations at both ends of the Pacific to network and share their valuable experiences."

Monte Jade sponsors a large annual meeting that typically draws an audience of more than 1000, as well as smaller monthly dinner meetings with speakers from the USA and Asia. Social events, both planned and unscheduled, are often as important as professional activities, and typically include families as well as members. Copies of the association's monthly newsletter, which are in Chinese and report on recent activities and individual accomplishments, are distributed to members in Silicon Valley and Taiwan.

The growth of the Taiwanese economy combined with active government recruitment and the formation of Monte Jade ultimately spurred a reversal of the 'brain drain'. Lured by the promise of economic opportunities as well as the desire to return to families and contribute to their home country, engineers began to return to Taiwan in growing numbers during the 1980s and 1990s. Approximately 200 engineers and scientists returned to Taiwan each year during the 1980s. By the mid-1990s, some 1000 were returning annually. Government officials report that by 1998 more than $30 \%$ of the engineers who studied in the USA had returned to Taiwan, compared with only $10 \%$ in the 1970 s.

The growth of the HSIP over the past decade reflects these trends. In the early 1980s the HSIP attracted only a handful of returnees each year. In 1990 the Park had attracted 422 returnees cumulatively. By 1997 the cumulative total had increased five-fold to over 2850 (figure 1) - with an average of 350 returning each year (HSIP, 1998). Moreover, these returnees are disproportionately likely to start their own businesses. Almost half of the companies in the Science Park (97 companies) in 1997 were started by US-educated engineers, many of whom had considerable managerial or entrepreneurial experience

(3) The Park administration offers a wide range of fiscal incentives for qualified technology investments, including low-interest loans, a five-year income tax break for the first nine years of operation, the right to retain earnings of up to $200 \%$ of paid-in capital, accelerated depreciation of R\&D equipment, and low-cost land. Equally important, it provides returnees with preferential access to scarce high-quality housing and to the only Chinese-American school in Taiwan - both of which are located on the park grounds. 


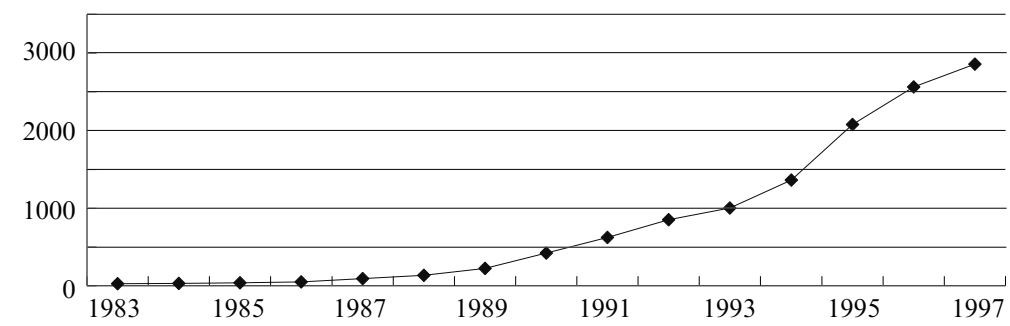

$\longrightarrow$ The total population of returnees

Figure 1. The total population of returnees in the Hsinchu Science-based Industrial Park. Returning entrepreneurs have started 97 companies in the Park, or $40 \%$ of the total (source: HSIP, 1998).

in Silicon Valley (HSIP, 1998). Many, like Miin Wu, in turn actively recruit former colleagues and friends from Silicon Valley to return to Taiwan.

In addition to these permanent returnees to Taiwan, a growing population of 'astronauts' work in both places and spend much of their lives on airplanes. Although their families may be based on either side of the Pacific (most often they live in California because of the lifestyle advantages), these engineers travel between Silicon Valley and Hsinchu once or even twice a month, taking advantage of the opportunities to play middlemen bridging the two regional economies. They include many Taiwanese angel investors and venture capitalists as well as executives and engineers from companies with activities in the two regions. This lifestyle is, of course, only possible because of the improvements in transportation and communication technologies. However it does not mean these astronauts are rootless. Their dense personal networks and intimate local knowledge of both Silicon Valley and Hsinchu play a central role in sustaining and coordinating the economic linkages between the two regions.

Even engineers who remain in Silicon Valley are typically integrated into the transnational community. Many work for start-ups or large firms with activities in both regions. Others moonlight as consultants on product development or provide market intelligence for Taiwanese firms. As a returnee-turned-entrepreneur illustrated, "If you want to work for Hsinchu, you don't have to go back. You might stay at Silicon Valley as usual, but work for Hsinchu as a subcontracting software engineer or IC designer" (James Ni, interview, 9 May 1999). Others return to Taiwan regularly for technical seminars sponsored by government agencies or professional associations like the CIE. In the words of another engineer who worked for IBM in Silicon Valley for eighteen years before returning to Taiwan: "There's a very small world between Taiwan and Silicon Valley" (Barnathan, 1992). Others say that Taiwan is like an extension of Silicon Valley.

\section{Cross-regional collaboration and reciprocal upgrading}

A community of Taiwanese returnees, astronauts, and US-based engineers has become the bridge between Silicon Valley and Hsinchu. As a result, what was once a one-way flow of technology and skill from the USA to Taiwan has become a two-way thoroughfare allowing producers in the two regions to collaborate to enhance their distinctive but complementary strengths. Fred Cheng, who runs Winbond North America and has worked in Silicon Valley for twenty years claims: "The best way to start a technology company today is to take the best from each region, combining Taiwanese financial and manufacturing strength with Silicon Valley's engineering and technical skill” (interview, 25 March 1997).

This appears to be a classic case of the benefits of comparative advantage. However, it is important to note that the economic gains from specialization and trade 
depend in this case on the social structures and institutions that insure continuous flows of information and facilitate joint problem-solving between producers located in distant regions. The social ties of a transnational community are especially crucial in today's fast-paced and competitive market environment.

The growing integration of the technical communities in the two regions has created new patterns of cross-regional collaboration. In some cases, collaboration occurs between the specialized divisions of a single firm. This includes start-ups such as Macronix (based in Hsinchu with a design center in Silicon Valley) and ISSI (based in Silicon Valley with a manufacturing division in Hsinchu) as well as larger, more established companies such as Acer (headquartered in Taiwan with a division in Silicon Valley). In these cases, the division managers are well connected in the local labor market and technical community and also have close trust-based working relationships with their colleagues in the main office. This allows them to avoid many of the problems that corporations have when they seek to acquire technology in foreign locations such as Silicon Valley. They need to be able to integrate into local social networks to gain access to technology and market information, while simultaneously being able to communicate quickly and effectively with decisionmakers in the headquarters (Deng, 1998).

Transnational entrepreneurs can quickly identify promising new market opportunities, raise capital, build management teams, and establish partnerships with other specialist producers - even those located at great geographical distances. The speed of personal communication and decisionmaking within transnational communities accelerates learning about new sources of skill, technology, and capital, and about potential collaborators. It also facilitates timely responses. This decentralized responsiveness is difficult for even the most flexible and decentralized multinational corporations.

Ken Tai is a good example. Tai joined several classmates from Chaiotung University to start Multitech, the forerunner of Acer, in the 1970s. After working for seventeen years at Acer he joined two more recently founded Taiwanese technology firms, Umax and EverMedia, before starting the venture capital firm InveStar. In 1996, its first year of operation, the firm invested $\$ 50$ million in Silicon-Valley-based start-ups. Tai sees InveStar as the bridge between Silicon Valley's new product designs and technology and Taiwan's semiconductor manufacturing and system integration capabilities:

"The new technology is all in Silicon Valley, but when you want to integrate that technology into a final product, Taiwan is the best place. Taiwan is the best place to integrate technology components together in a very efficient way because it excels at production logistics and information handling."

Tai goes on to describe InveStar's role as an intermediary in this process:

"When we invest in Silicon Valley startups we are also helping bring them to Taiwan.

It is relationship-building ... we help them get high-level introductions to the semiconductor foundry and we help establish strategic opportunities and relationships in the PC sector as well. This is more than simply vendor-customer relationships. We smooth the relationships" (interview, 6 May 1997).

The case of Platform Technology, a Silicon Valley start-up founded by a USeducated Chinese entrepreneur, Paul Tien, illustrates the benefits of the cross-Pacific relationships (Herbert Chang, interview, 22 July 1997). InveStar invested \$3 million in Platform in 1996 when the firm was already several years old and was struggling to find customers, in spite of its state-of-the-art audio chip design. The partners at InveStar introduced Tien to senior executives at the leading PC companies in Taipei. Platform quickly became known within Taiwan's technology circles, and got so many design contracts that it quickly became one of the world's largest producers of audio chips. 
Platform was also having problems with the manufacturing process at its foundry, Taiwan Semiconductor Manufacturing Corp (TSMC). As a small US-based start-up they could not get the attention of the giant chip manufacturer. Once again, the InveStar partners intervened by calling their friends at TSMC. They made sure that Platform's calls were returned and that its problems were addressed immediately.

One year later, Platform was so successful that it posed a major threat to ESS, another Chinese company in Silicon Valley that had historically dominated the PC audio chip market. In early 1997, ESS founder Fred Chen called the InveStar partner who had previously worked with ESS and asked what he could do to help. As a result of these conversations, InveStar arranged the sale of Platform to ESS. They coordinated a very small, simple acquisition - one that was done completely informally. There were no lawyers involved; in fact there was nothing written. This was the sort of trust-based deal that could only be made by partners who have complete confidence in one another.

\section{Is it a story of guanxi capitalism?}

Students of Chinese capitalism would tend to link the above illustration to the role guanxi played in the development of Chinese business networks. It is easy to observe the elements of social embeddedness such as trust, goodwill, and mutuality in the interregional connection and thus it is easy to jump to the conclusion: it is just another version of guanxi capitalism. However, such a guanxi discourse downplays the complementary knowledge-competency, and it overemphasizes the intertwined social network between these two regions. In guanxi capitalism, business will be personalized and will be governed by the construction of interpersonal ties. As some scholars (Cheng, 1999; Wu J-M, 1997) have criticized guanxi construction as rent-seeking in traditional sectors such as the footwear and garment industries, it is particularly critical to avoid cronyism in the high-technology sectors which compete in an extremely turbulent environment. For example, high-ranking managers are not allowed to hire their relatives in the United Microelectronics Company (UMC). Most HSIP insiders recognize that the relatively poor performance of the Hualon Microelectronics Corporation is a result of a power struggle among the founding family members (Hsu, 1997). Close ties will sometimes become blind trust, and make firms unconscious of exterior technological breakthroughs or new business opportunities. To make things worse, the guanxi-embedded system occasionally compels people to compete more on the basis of the thickness of the tie than on the depth of capability. In other words, a guanxi-rich industrial world without cautious monitoring might lead to an unproductive situation, rather than a healthy and efficient production system. The peril of lock-in is usually put to one side by the guanxi capitalism (as well as networked firm) argument (compare Grabher, 1993).

Even those business people who are deeply involved in cross-region networks take a wary attitude to the ethnic-orientation circle. Macronix International Co. (MXIC) is a case in point. It was established by a group of thirty-eight Silicon Valley returnees led by $\mathrm{Mr}$ Miin Wu, the president. They regularly recruit people from Silicon Valley to strengthen their innovative capabilities, according to $\mathrm{Wu} .{ }^{(4)}$ Besides luring skilled people back to Taiwan, MXIC also set up a technical development and marketing department in San Jose as a listening post to tap into the powerhouse of IC product innovation.

(4) $\mathrm{Wu}$ valued the returnee talents very much. He argued, "were it not for these adept engineers, MXIC would not have been able to stay on the right track. The upgrading of product levels could not have been possible without their inputs. To remain on the technology frontier, we had to recruit new engineers from Silicon Valley every year. I went to Silicon Valley to find the right people every year. They are like the roots of a tree, absorbing nutrients from outside. You've got the right people, you've got the right technology" (Common Wealth 1995). 
Through this department, MXIC subcontracted some product-development jobs to overseas Taiwanese engineers. The department allowed those engineers who were reluctant to return to Taiwan to contribute their knowledge and experience to MXIC.

MXIC recruited qualified engineers through several channels, beginning with the social networks of the founders. Most of the information was based on colleagial or classmate relationships. In most situations, the employers at MXIC evaluated materials relating to targeted engineers and then approached them informally. They preferred those engineers who had an established reputation. Information contact was believed to be the most effective way to get the necessary and accurate information about the targeted engineers. In some cases, official recruiting methods were adopted when qualified engineers were not available informally. MXIC usually publicized job positions in the Shi-Jie-Ri-Bau (World Journal), a popular Chinese newspaper distributed in Silicon Valley. Sometimes, it would also participate in the semiconductor job fair sponsored by the Chinese-American Semiconductor Association. Nevertheless, the case of MXIC demonstrated that ethnic ties helped the firm swiftly to identify qualified engineers and lowered transaction costs in the head-hunting process. In other words, the guanxi webs make it easy to turn know-who into know-how in a knowledge-based economy.

However, we should not stop here. While recognizing the guanxi's role as the lubricant in labor recruiting, $\mathrm{Wu}$ warned it is not a story exclusive to overseas Chinese. He raised the issue of a technical community to challenge the idea of a guanxi enclave. After illustrating the close tie between MXIC and the Silicon Valley Chinese engineer community, Wu added, "Of course we look for qualified Chinese talents, and in most time, it is easier to get the information about the candidates' reputation if they are Chinese. But we do not target on Chinese in itself. We search for qualified engineers. That's our top priority in the evaluation process. It is stupid to hire a guy just because he is in my circle. We hire people based on their competence, not their guanxi or ethnicity. Guanxi helps us to get the right people easily, but it does not mean we exploit the advantage of guanxi itself. The key issue here is that all the people we hire are professional engineers, and they happen to be Chinese" (interview, 12 May 1998).

The cautious attitudes toward guanxi exist not only in intrafirm and employment relationships, but also in interfirm relationships. Trust is the key component created by guanxi to lubricate interfirm interactions. However, even if we agree that guanxiembedded trust does matter in the transaction process, we still have to distinguish trust incubated by ethnic ties from that bred by learning. In most cases, firms place subcontracting orders with other firms (even those with close ethnic or classmate ties), in small volumes at the beginning. Then they place more orders after the first ones have been reviewed on merit. It is the transaction process that thickens the social fabric, rather than vice versa. As David Lee, who placed the first original equipment manufacturing order for Taiwan's PC firms in the early 1980s, argued, "We took first move to look for Taiwan's clone computer manufacturers, because I knew Taiwan's industrial strength very well. I have known people such as Stan Shih (of Acer) and Mathew Miau (of Mitac) before they became famous afterwards. However, I placed the order in small volume (totally US\$30 million), to test their manufacturing capabilities, and then I thought they could make it. I placed a bigger order after the several small orders. I trust them not just because they are of the same ethnicity as mine, but because they pass my tests" (Deng, 1998, page 49). ${ }^{(5)}$ It is particularly true that, although the Taiwanese firms in both regions could resort to nothing but ethnic ties in the mainstream

(5) Miau attributed the early succes of Mitac to Lee's order, because Mitac was a small company then and no other big players in the PC industry were willing to trust Mitac. "Only Chinese understand Chinese and dare to give us order to try, and believe we can make it" argued Miau in an interview (Deng, 1998, page 49). 
business in their embryonic stages, guanxi could render the information collection cross the Pacific easy. Trust and reciprocity incubated from primary ethnic bonds and informal personal relationships facilitate the cooperation between these regions, and broaden the scope of guanxi building. In principle, guanxi provides the basic ingredients for the two regional ethnic communities to build up trust for business in the beginning. However, trust should be monitored and refined, and thus could grow to allow lasting cooperative behavior. Although these two types of trust cannot be empirically separated, they should be treated as theoretically different. Guanxiembedded trust helps cross-border firms engaging in initial cooperative business, but monitoring-created trust insures the deepening of these deals. Although we agree that guanxi and cultural affinity could provide the precise channel for valuable information to flow, we disagree that interpersonal relationships by themselves would create a faithful industrial community which could collaborate. We do not argue here that there is ineludible contradiction between social ties and economic rationality (compare Wu S-H, 1999), but a thorough taxonomy of trusts and their embodied functions in business activities is essential for a dynamic analysis (Powell, 1996).

\section{Conclusion}

The role of social ties in economic activities is a hot issue in current "new economic geography" (Thrift and Olds, 1996), and the boundary between the economic and the cultural is becoming blurred (Lee and Wills, 1997). In cultural turns, economic behaviors are believed not only to be embedded in social networks, but also are defined by cultural identities (Sayer, 1997). In this sense, the diverse forms of social organization and cultural setting will contextualize economic activities and produce different forms of geographical-economic system. Under such circumstances, some sociological terms such as trust, reciprocity, networks, and embeddedness gain legitimacy by floating over in the literature of economic geography. In the new social economy, the Chinese business system is often raised as a contrasting case against the typical market economy of the West (Hamilton and Biggart, 1988; Thrift and Olds, 1996; Yeung, 1998). Interpersonal relationships, or guanxi, are argued to be socially richer than market rationality in fabricating economic behaviors in Chinese business circles. In a sense, guanxi means business in Chinese societies, even overseas ones. The idea of the market as a social constitution rightly stitches the lacuna of the discourse of market rationality, and discovers the rich economic lives in the modern global business system. However, such a portrait of Chinese business networks commits an oversocialized fallacy, which mixes up social logic and economic rule without making a theoretical distinction between them. While social ties engender trust for firms to save transaction costs in business activities, and allow firms to engage in cooperative organization, social factors do not replace market mechanisms as the dominant form of governance in business systems, even ethnic economies. The boundary between the social and the economic is really blurring, but they are not mixed together. These two organizational fields overlap in some parts of real business practice, but remain relatively autonomous in others, as the business system evolves. Nevertheless, the social matters, but never determines. Here we echo Sayer (1997) and Mitchell (1997) who insist on the relevance of economic reasoning and capital logic in the analysis of today's "new social economy" and transnational cultural economy, while recognizing the subtle difference in local contextualization of global economic connections.

The case of the Silicon Valley-Hsinchu connection illustrates the potential of and limit of ethnic ties in business transactions. On the one hand, the ethnic bond allowed overseas Chinese entrepreneurs take advantage of the complementary assets of the two regions: exploiting the business opportunities across the Pacific, and recruiting talented 
engineers from the experienced Chinese technical pool. However, the guanxi-embedded circle does not necessarily transform into a technical community for both regions to constitute the dynamic advantage of technological learning. Goodwill embodied by guanxi produces motives for ethnic firms across the Pacific to cooperate, but not the essential resources for firms in both regions to build up their competitive competence. Guanxi matters, but never determines in overseas Chinese business networks. The argument of guanxi capitalism just goes too far.

Acknowledgements. The authors express their gratitude for financial supports from Chiang Ching-Kuo Foundation for International Scholarly Exchange and Taiwan's National Science Council (grant \#: NSC 89-2415-H-003-007-).

\section{References}

Barnathan J, 1992, "Bringing it all back home" Business Week 7 December

Borrus M, 1997, "Left for dead: Asian production networks and the revival of US electronics", in The China Circle: Economics and Technology in the PRC, Taiwan, and Hong Kong Ed. B Naughton (Brookings Institution Press, Washington, DC) pp 139- 163

Castells M, 1996 The Rise of the Network Society (Blackwell, Cambridge, MA)

Cheng L-L, 1999, "The invisible elbow: semiperiphery and the restructuring of international footwear market" Taiwan: A Radical Quarterly in Social Studies 351 - 46 (in Chinese)

Common Wealth 1995, "Returnee entrepreneurs: the story of Taiwan's high-technology development", October, pages $128-131$

Cox K (Ed.), 1997 Spaces of Globalization: Reasserting the Power of the Local (Guilford Press, New York)

Deng H-C, 1998 The Legend of Silicon Valley 2 volumes (Yuan Shen Press, Taipei) (in Chinese)

Dicken P, 1998 Global Shift: Transforming the World Economy 3rd edition (Guilford Press, New York)

Dicken P, Yeung H W-C, 1999, "Investing in the future: East and Southeast Asian firms in the global economy", in Globalisation and the Asia-Pacific: Contested Territories Eds P Kelly,

L Kong. K Olds (Routledge, London) pp $107-128$

Dunning J, 1997 Alliance Capitalism and Global Business (Routledge, London)

Gereffi G, Korzeniewicz M (Eds), 1994 Commodity Chains and Global Capitalism (Praeger, New York)

Grabher G (Ed.), 1993 The Embedded Firm: On the Socioeconomics of Industrial Networks (Routledge, London)

Granovetter M, 1985, "Economic action and social structure: the problem of embeddedness" American Journal of Sociology 91481 - 510

Granovetter M, 1995, "The economic sociology of firms and entrepreneurs", in The Economic Sociology of Immigration Ed. A Portes (Rusell Sage Foundation, New York) pp 128-165

Guthrie D, 1998, "The declining significance of guanxi in China's economic transition" The China Quarterly $154254-282$

Hamilton G, 1996, "The organization of business in Taiwan” American Journal of Sociology 96 $999-1006$

Hamilton G, Biggart N, 1988, "Market, culture, and authority: a comparative analysis of management and organization in East Asia" American Journal of Sociology 94 (supplement) S52-S94

Hirst P, Thompson G, 1996 Globalization in Question (Polity Press, Cambridge)

Hsing Y-T, 1997, "Building guanxi across the Straits: Taiwanese capital and local Chinese bureaucrats", in Ungrounded Empires: The Cultural Politics of Modern Chinese Transnationalism Eds A Ong, D Nonini (Routledge, London) pp 143 - 166

Hsing Y-T, 1998 Making Capitalism in China: The Taiwan Connection (Oxford University Press, New York)

HSIP, 1998 Yearly Statistical Book of the HSIP Administration of the Hsinchu Science-based Industrial Park, Hsinchu

Hsu J-Y, 1997, “A late industrial district? Learning networks in the Hsinchu Science-based Industrial Park, Taiwan", dissertation, Department of Geography, University of California, Berkeley, CA

Hsu J-Y, 1999, "The technological development of Taiwan's semiconductor industry: state intervention, cross-border social networks and high technology", paper presented at The Conference for the Development of Technology in Taiwan's Industrialization Process, Kaoshung 28-29 December (in Chinese); copy available from the author 
Kao J, 1993, “The worldwide web of Chinese business" Harvard Business Review March-April, $24-36$

Kotkin J, 1992 Tribes: How Race, Religion, and Identity Determine Success in the New Global Economy (Random House, New York)

Lee R, Wills J (Eds), 1997 Geographies of Economies (Arnold, London)

Lin J, 1998 Reconstructing Chinatown: Ethnic Enclaves, Global Change (Minnesota University Press, Minneapolis, MN)

Lundvall B-A, 1996, "The social dimension of the learning economy", WP 96-1, Danish Research Unit for Industrial Dynamics, Aalborg University, Aalborg, Denmark

Mitchell K, 1997, "Transnational discourse: bringing geography back in" Antipode $29101-114$

Powell W, 1996, "Trust-based forms of governance", in Trust in Organizations Eds R Kramer, T Tyler (Sage, Thousand Oaks, CA) pp $51-67$

Sabel C, 1989, "Flexible specialization and the re-emergence of regional economies", in Reversing Industrial Decline? Eds P Hirst, J Zeitlin (St Martin's Press, New York) pp 17-70

Sabel C, 1994, "Learning by monitoring: the institutions of economic development", in The Handbook of Economic Sociology Eds N Smelser, R Swedberg (Princeton University Press, Princeton, NJ) pp $137-165$

Saxenian A, 1994 Regional Advantage: Culture and Competition in Silicon Valley and Route 128 (Harvard University Press, Cambridge, MA)

Saxenian A, 1999 Silicon Valley's New Immigrant Entrepreneurs (Public Policy Institute of California, Oakland, CA)

Saxenian A, Hsu J-Y, 1999, "Transnational entrepreneurs and regional industrialization: the Silicon Valley - Hsinchu connection", paper presented at the 1999 Annual Conference, Association of Collegiate Schools of Planning, Chicago, IL, 21 - 24 October; copy available from the authors

Sayer A, 1997, "The dialectic of culture and economy" Geographies of Economies Eds R Lee, J Wills (Arnold, London) pp 16-26

Scott A, 1998 Regions and the World Economy: The Coming Shape of Global Production, Competition and Political Order (Oxford University Press, Oxford)

Seagrave S, 1995 Lords of the Rim: The Invisible Empire of the Overseas Chinese (Putnam, New York)

Storper M, Salais R, 1997 Worlds of Production: The Action Frameworks of the Economy (Harvard University Press, Cambridge, MA)

Thrift N, Olds K, 1996, "Refiguring the economic in economic geography" Progress in Human Geography $20311-337$

Wong S-L, Salaff J, 1998, 'Network capital: emigration from Hong Kong” British Journal of Sociology $49358-374$

Wu J-M, 1997, "Strange bed-fellows: dynamics of government - business relations between Chinese local authorities and Taiwanese investors" Journal of Contemporary China 6315 - 346

Wu S-H, 1999, "Dynamic production networks in the IC industry", in Corporate Networks in Taiwan Ed. L-Y Chang (Yuan Liou Pres, Taipei) (in Chinese) pp 56-113

Yeung W-C, 1998 Transnational Corporations and Business Networks: Hong Kong Firms in the ASEAN Region (Routledge, London)

Zhou M, 1992 Chinatown: The Socioeconomic Potential of an Urban Enclave (Temple University Press, Philadelphia, PA) 
